\title{
Progress Towards Attainment of Education for All (EFA) among Nomadic Pastoralists: How Do we Dismantle the Gender Differential Jinx in Mandera County, Kenya?
}

\author{
${ }^{*+}$ John Aluko Orodho ${ }^{1}$, Peter Ndirangu Waweru ${ }^{2}$ and Kennedy N.Getange ${ }^{4}$ \\ Department of Educational Management, Policy and Curriculum Studies, Kenyatta University, Kenya \\ ${ }^{2}$ Peter Ndirangu Waweru, PhD Student, School of Education, Mount Kenya University, Kenya. \\ ${ }^{3}$ Kennedy Nyambeche Getange, PhD; recently graduated Doctoral Student, School of Education, Kenyatta \\ University
}

\begin{abstract}
The purpose of this paper is to document the current strategies put in place in Kenya towards the attainment of education for all (EFA) and millennium development goals (MDGs) among nomadic pastoralists the country. The guiding question is how can we dismantle the gender differential jinx hampering attainment of educational equity in Mandera County? The paper uses a combination of secondary and primary data sources. The primary data was obtained from a sample of 45 teachers undertaking their school-based degree programmers at Kenyatta and Mount Kenya Universities. Mixed methods employing both quantitative and qualitative approaches were used to analyze the data. It was found that despite the milestones achieved towards attaining EFA and MDGs in Kenya at the national level, Kenya still faces a number of challenges; some of them have significantly thwarted the possibilities of improving access and quality of education especially in nomadic pastoralist study areas of Mandera County of the country. The critical factors hindering the attainments of the targets include: poverty and the high cost of education as a result of uncontrolled latent user-charges introduced at school level, negative and retrogressive socio-cultural practices that specifically impact on the girl child, un-conducive learning environment due to schools that are not child-friendly, and insecurity among others. It is commended that strategies to dismantle the gender differential jinx in Mandera County should focus more sharply on the girl-child by using instructional techniques favourable to the girl-child, intensify the support to low-cost girls boarding schools and mobile schools to continue educational provision during nomadic shifts by parents, expand child-friendly schools and intensify peace education as well as education in emergency, among others. [256 words ].

Key words: Education for all (EFA), Millennuim Development Goals (MDGs), Nomadic pastoralists, equal opportunities, Gender jinx, access and quality education, pragmatic policies.
\end{abstract}

\subsection{Background}

\section{Introduction}

Education in Kenya-as elsewhere in the world- is a basic and fundamental human right (Republic of Kenya, 2010a, 2012a, United Nations, 2013). Like all human rights, it is universal and inalienable - everyone, regardless of gender, religion, ethnicity or economic status, is entitled to it. In 1990, Kenya was among the international community that gathered in Jomtien, Thailand, to affirm its commitment to achieving universal education at the World Conference on Education for All (Republic of Kenya, 2012a 2012b, 2013). As part of the resulting EFA (Education for All) initiative, a broad coalition of governments, NGOs and development agencies committed themselves to six goals aimed at providing education to "every citizen in every society": Expanding and improving early childhood care and education, especially for the most vulnerable children; Ensuring that by 2015, all children, particularly girls and the disadvantaged, have access to quality free and compulsory primary education; Eliminating gender disparities in primary and secondary education by 2005, and achieving gender equality in education by 2015; Ensuring that the learning needs of all young people and adults are met through equitable access to appropriate learning and life skills programmes; Achieving a 50 percent improvement in levels of adult literacy by 2015 , especially for women, and offering equitable access to basic and continuing education to all adults; Improving all aspects of the quality of education and ensuring excellence ( Republic of Kenya,2012c Republic of Kenya/UNESCO,2012; World Education Forum,2000; United Nations, 2013). Underlying these goals is the realization that mere access to education is not sufficientthe quality and duration of education is equally important (United Nations, 2005a, 2011, 2013; UNESCO,2004a ,2004b, 2012). However, globally, there is an education learning crisis (Brookings Institution, 2013). Some 60 million primary school-age children and 71 million adults do not attend school (Brookings Institute, 2013; United Nations, 2005b, 2013). In many developing countries, less than 60 percent of primary school pupils who 
enroll in first grade reach the last grade of schooling. Children must not only enroll in school; they must complete it; and human rights values and principles must be the guiding force in the classroom (UNICEF, 2013 UNESCO, 2005a; 2005b ,2011).

The EFA agenda assumes that public policy can radically transform education systems and their relation to society given adequate political will and resources, and that national policies and implementation must emphasize inclusion, literacy, quality and capacity development (Republic of Kenya, 2001, 2005a, 2012a). In 2000, with targets far from being met, Kenya was one of the 164 countries who attended the World Education Forum in Dakar, Senegal, and adopted the Dakar Framework for Action, which reaffirmed the EFA goal of achieving quality basic education for all by 2015, with particular emphasis on girls' education. Later that year, two EFA goals were incorporated in the Millennium Development Goals (MDGs) for achieving universal primary education, promoting gender equality and empowering women (World Education Forum, 2000). Indeed, EFA goals are critical to attaining all the MDGs. Education can improve health, increase environmental sustainability and help eradicate poverty and hunger. It is envisaged that in turn, achieving the MDGs will help children-both boys and girls- access and benefit from quality education.

\subsection{Setting the Foundation through international and national commitments Convention on the Rights of the Child}

The Convention of the Rights of the Child (CRC) was established in 1989 as the first internationally binding legal instrument to encompass the full range of human rights -civil, political, economic, cultural and social - and codified the concept of human rights specifically applicable to children. Article 12 proclaimed that children are entitled to express their views on all matters of concern to them, and this norm in turn applies to all aspects of childhood education. According to the UNESCO EFA Global Monitoring 2009 Report, the principle of participation was buttressed in the Convention, with parallel rights to freedom of expression, religion, and association. Article 28 of the Convention addresses education and specifies that all children have the right to primary education, which should be free for all (Republic of Kenya,2001,2010a 2010c).

\section{Beijing in 1995}

The Beijing Conference in 1995, the Fourth World Conference for Women, set out abroad Platform of Action (BPFA) concerning the girl child. Drawing on baseline statistics from 1990, 130 million children worldwide had no access to primary education, of which 81 million were girls (UNESCO, 2005a, 2005b, 2012). A considerably higher number of girls had no access to secondary education. According to the UN Division for the Advancement of Women, BPFA acknowledged the urgent need to:

$\square$ increase girls' access to primary and secondary education

alter representations of women and girls in the curriculum, and

$\square$ increase the number of female teachers worldwide.

Strategic Objective L4 stated the need to 'eliminate discrimination against girls in education, skills development and training'. Without significant change to traditional curricular representations of women in roles of inferiority, girls would find it difficult to aspire to transcend these roles and work toward gender parity. Moreover, female teachers must be trained and placed in schools to serve as positive role models for young girls, both in primary and secondary schools. Through these threefold changes, Beijing set out a transformative path for the 21st century toward gender equality for the girl child (World Education Forum, 2000). This path proved the foundation for the agenda of the Dakar World Educational Forum in 2000 and the formation of the MDGs to be accomplished by 2015 Educational Forum in 2000 and the formation of the MDGs to be accomplished by 2015( UNESCO,1990 ; World Education Forum,2000).

\section{Dakar World Educational Forum (2000)}

The World Educational Forum, held in Dakar, Senegal in 2000, established a Framework of Action to achieve Education for All (EFA) by 2015. EFA Goal II is to achieve universal primary education (UPE), and EFA Goal V is to remove gender disparities and inequalities in education. The Framework of Action was further divided into a two-part agenda:

Gender parity in school participation, and

Equality between girls and boys in opportunities and outcomes

The dominant tone in the World Forum was that girls and boys should have equal and full access to primary education worldwide, and should complete primary school with equal preparation and assistance to facilitate passage of required examinations and entrance into secondary school. Throughout schooling, girls and boys should experience both equal preparation and treatment, within the classroom by teachers and by school advisors, such that girls and boys will emerge with comparable skills sets to enter the workforce. 


\section{Millennium Development Goal 3}

The MDGs, established also in 2000 at the United Nations Millennium Summit and signed by 189 heads of state around the world, outline a list of eight overarching goals for developing countries to achieve by 2015. Among this list, Goal 3a is to 'eliminate gender disparity in primary and secondary education, preferably by 2005 , and at all levels by $2015^{\prime}$ '. Indicator 9 , to measure the promotion of gender equality and empowerment of women, is the ratio of girls to boys in primary, secondary and tertiary education. As elaborated in a presentation on MDG Goals1, Indicator 9 sets an important precedent for the achievement of the following three indicators: Indicators 10, 11 and 12, which entail the ratio of literate females to males of in the 15-24 age range, the share of women in wage employment in the non-agricultural sector, and the proportion of seats held by women in national parliament, respectively. Thus MDG 3 sets a high priority on ensuring girls' equal access to primary and secondary education (as well as tertiary) in order to achieve the broader objective of gender equality and empowerment of women and girls.

\subsection{Domesticating international concerns in Kenya}

The foregoing section underscores the fact that education is fundamental human right enshrined in the Universal Declaration of Human Rights (United Nations,1984), and the international community and national governments have committed themselves to implementing EFA as a moral ,political and legal obligation. The Universal Declaration of Human Rights, the World Conference on EFA (UNESCO,1990), and the World Education Forum ( Republic of Kenya,2009a, UNESCO,2000) are acknowledgements by the international community of the strategic role that education plays in social, political and economic arenas, as well as in development. The spirit of EFA is developed further in the Millennium Development Goals (MDGs) on education, which aim to ensure that children everywhere will be able to complete whole course of primary schooling by 2015. As Kenya is a signatory to all the international conventions and protocols, including the EFA Dakar declaration, the Government of Kenya launched the National Action Plan (NAP) on EFA in 2003. The Kenyan Constitution in Article 53 part 1(b) states that every child has the right to free and compulsory basic education. It is therefore the obligation of the Government to ensure that all children are provided with education of good quality (Republic of Kenya, 2010a). While the global term UPE refers to primary education, an expanded view is provided in Kenya where basic education encompasses early childhood care and education, primary and secondary education, hence referring to Goal 2 as Universal Basic Education (UBE).

To domesticate international conventions and also address national aspirations, the Government of Kenya has adroitly formulated laws and put in place legal frameworks including the Children's Act 2001, the Sessional Paper No.1 of 2005, the Sessional Paper No.14 of 2012; the Disability Act of 2003, the Basic Education Act 2013 all as legislative basis for providing education for all(Republic of Kenya, 2003, 2005,2012,2013).In addition, the Government of Kenya has also put in place specific policies to target the hard to reach and the historically marginalized communities, especially those residing in ASALs, particularly the nomadic pastoralist communities.

For example, the Policy for Nomadic Education in Kenya was put in place in 2006 to address the plight of nomadic communities. This was in recognition of the fact that Kenya's pastoralist and nomadic communities, who are the dominant groups in ASALs, have not fully benefited from education provision, primarily due to their mobile lifestyle. This investment program targets alternative, flexible, community-based learning approaches that suit the nomadic nature of communities in ASALs. The rationale for this programme is that in spite of the success of the FPE programme, some areas continue to show poor enrolment rates, particularly in primary schools (Republic of Kenya, 2005b, 2006). The overall aim of this programme is to increase access to education for children living in ASALs, especially girls and children with special needs, through identification and application of alternative approaches to provision of education. The total estimated cost for setting up mobile schools will be KSh 117 million over a five-year period between 2005 and 2010 (Republic of Kenya, 2007a, 2007b ,2009a, 2009b,2010c, 2013).

The Government of Kenya is implementing the Policy Framework for Nomadic Education in Kenya in injunction with UNICEF, the focus of which is to provide guidelines for the coordination and harmonization of educational service delivery for nomadic communities in Kenya. Equity is being achieved through establishment of:

...three hundred and ninety two (392) low-cost boarding schools with an enrolment of 110,490 pupils; ninety one (91) mobile schools with an enrolment of10, 631 pupils; and Education under emergency programmes is being implemented and a unit has been set up at the MoE; Peace Education initiatives are being implemented and have been incorporated into the curriculum; and the life skills curriculum has been developed and is being used in schools (Republic of Kenya/UNESCO, 2012). 
There is little doubt from the foregoing that the Government of Kenya in collaboration with education development partners has well focused intentions to ensure that indeed nobody is left behind in the educational provision. The Government of Kenya is also in the process of irrationalizing the mainstreaming policy for the support of most vulnerable children (MVCs) which is basically meant to target orphans and vulnerable children (OVCs). The components of this intervention will include: Cash-subsidies to those caring for OVCs; provision of bursaries for students in need; provision of meals in ASAL and slums; and support to rescue, protection and rehabilitation centers. Since 2005, 3,250 schools and 500,000 learners have benefited from the Most Vulnerable Children (MVC) support grant, which had disbursed Ksh 610 million by 2010( Republic of Kenya,2011, Republic of Kenya/UNESCO,2012).

The other innovative initiatives aimed at accelerating achievement of EFA, especially in the marginalized communities are; child-friendly schools, school health-feeding and nutrition initiative and gender in education policy. The government and UNICEF initiated the Child-Friendly School (CFS), whose aim is: to make schools friendly to learners to enhance access and retention; and also train teachers to use child friendly modes of curriculum delivery through School-based Teacher Development (SbTD). So far over 8,000 teachers (including ECDE and NFE teachers) drawn from 1,321 primary schools with an enrolment of more than 1.6 million children in 11 districts, have been trained in CFSI in the financial year 2010/2011( Republic of Kenya, 2012a, 2012b; Republic of Kenya/UNESCO,2012).

With regards to the School Health- feeding and Nutrition Initiative, the MoE developed the Policy in 2008, with the aim of improving learner health and nutrition in order to sustain their participation and performance in their education (Republic of Kenya, 2008). A total of 1.3 million primary and pre-primary children receive mid-day meal, and over 125,000 pre-primary children receive micronutrient supplementation in the form of a mid-morning snack ( Republic of Kenya,2008; Republic of Kenya/UNESCO, 2012).

The gender in education policy was adroitly crafted to reduce gender imbalances in access and participation in education. As a consequence, gender parity has improved in targeted provinces as has performance due to this programme. For example, gross enrolment ratio in the North Eastern province has increased from 19.3\% (boys25 .3\%, girls 13.3\%) in 2002, to 36.3\% (boys 50.15, girls 22.5\%) in 2010. In collaboration with UNICEF, the Government provides full scholarships to girls from ASALs who excel at Kenya Certificate of Primary Education level, to continue with secondary education (Republic of Kenya/UESCO, 2012).

\subsection{Statement of the Problem}

Despite the policy frameworks and innovative interventions to enhance education in Kenya, many children in North Eastern Province, in the country were not in school. Almost 80 percent of these children live in Mandera County, Kenya. For too many of these children, particularly the girls, the basic human right to education is a pipe dream, an idea that has not become a reality in less than two years to the EFA deadline of 2015 to achieve the six goals aimed at providing education to every citizen in every society. Fuelled by this realization, the purpose of this paper is to profile the progress towards attainment of education for all (EFA) among nomadic pastoralists in Mandera County. The main question that guided the paper is: how do we dismantle the gender differential jinx in Mandera County, Kenya? The paper first describes the foundations of girls' education at the beginning of the $21^{\text {st }}$ century in Kenya.

\subsection{The Research Methodology}

A cross-sectional descriptive survey of the perception of Kenya's primary and secondary school teachers on the levels of challenges introduced by the FPE and FDSE initiative conducted using semi-structured questionnaires. This instrument was pilot tested among eight primary school teachers undertaking their school based studies at Catholic University of Eastern Africa (CUEA). Based on the split-half technique, a reliability coefficient of .85 was obtained, and accordingly declared the questionnaire reliable (Brook, 2013). The target population for this study included all public primary school teachers in Kenya teaching in or residing in or around Mandera County, Kenya. A convenient sample of 45 undergraduate and postgraduate teachers undertaking the school-based bachelor of education and masters of education degrees at Kenyatta University and Mount Kenya University was selected for the study. The overall sample of 45 comprised 32 males and 13 females. Both secondary and primary data sources were used and analyzed using mixed methods involving qualitative and quantitative approaches. 


\section{Results and Discussion}

\subsection{Emerging Challenges and Concerns}

It was established that at national level, The Government of Kenya has made remarkable progress towards attainment of EFA Goal 5 on Gender Equity and equality in education and training. This is evident since Kenya is a signatory of major international conventions and agreements that address human rights, gender equity and equality. It was established that on this basis, various government ministries have developed policies safeguarding human rights, particularly those of women and children. There was little doubt that, at national level, Kenya has scored very highly with respect to attainment gender parity at all levels of basic education from ECDE , primary to secondary school levels. This trait has been demonstrated through innovative initiatives such as :development and implementation of gender in education policy; development of gender responsive curriculum, implementation of affirmative action on females enrollment to higher education by lowering of the expected grade points, provision of sanitary towels to girls in ASAL areas ,especially in nomadic pastoralist schools; establishment of low cost boarding and feeder schools to attract and retain learners especially from ASAL and nomadic communities; amongst others.

However, despite this remarkable progress towards attainment of gender equity in education at the national and provincial levels, there are emerging trends which when unpacked at county and sub-county levels and examined using a gender, show very disappointing development.

\subsection{Enrolment in ECDE in Mandera County}

The data carried in Table 1 indicates that although enrolment in ECDE in Mandera County shows that although some noticeable gender gap exists, the situation is not serious. At the county level, the enrolment ratio of boys to girls is 3:2, meaning that for every five children enrolled in ECDE, three are boys while two are girls.

Table 1: Enrollment in ECDE in Mandera County

\begin{tabular}{|l|l|l|l|l|l|}
\hline Sub-County & Male & Percent & Female & Percent & Total \\
\hline Mandera East & 1466 & 58.8 & 1041 & 41.2 & 2507 \\
Lafey & 808 & 63.4 & 466 & 36.6 & 1274 \\
Mandera West & 2115 & 62.8 & 1248 & 37.2 & 3363 \\
Barissa & 1421 & 62.8 & 840 & 37.2 & 2261 \\
Mandera Central & 2400 & 59.8 & 1700 & 40.2 & 4011 \\
Mandera North & 1655 & 58.7 & 1164 & 41.3 & 2819 \\
Total & 9,865 & 60.7 & 6,459 & 39.3 & 16,342 \\
\hline
\end{tabular}

It is very encouraging to note that in some sub-counties such as Mandera East and Mandera Central, gender parity at this level of education has nearly been achieved. The three sub-counties that still lag behind the progress towards attaining gender parity at this level are: Lafey, Mandera West and Barissa sub-counties. In these areas more needs to be done in encouraging girls to enroll into the ECDE level.

The data contained in Table 2 shows that the enrolment in primary schools in Mandera County shows a growing and widening gender gap at the disadvantage of the girl child. The gender gap is particularly more worrying in the sub-counties of Lafey, Barissa and Mandera West .In Lafey, out of 6,082 pupils enrolled, there are 4,981 boys constituting 81.8 percent and only 1,115 girls representing a mere 18.2 percent.

Table 2: Enrollment in Primary Schools in Mandera County

\begin{tabular}{|l|l|l|l|l|l|}
\hline Sub-County & Male & Percent & Female & Percent & Total \\
\hline Mandera East & 16705 & 62.3 & 10088 & 37.7 & 26793 \\
Lafey & 4981 & 81.8 & 1105 & 18.2 & 6082 \\
Mandera West & 7020 & 68.9 & 3162 & 31.1 & 10182 \\
Barissa & 4970 & 70.1 & 2087 & 29.9 & 7056 \\
Mandera Central & 7669 & 63.2 & 4473 & 36.8 & 12142 \\
Mandera North & 6355 & 59.2 & 4381 & 40.8 & 10736 \\
Total & 47451 & 66.7 & 24045 & 33.3 & 72995 \\
\hline
\end{tabular}

In Barissa sub-county, out of the 7,056 pupils enrolled in primary schools, there are 4,970 boys constituting 70.1 percent, compared to 2,087 girls constituting 29.9 percent. Similarly, in Mandera West sub-county, out of the 10,182 pupils enrolled, there are 7,020 boys constituting 68.9 percent compared to 3,162 girls representing 31.1 percent of the total enrollment.

Table 3 contains data which shows a very disappointing enrollment trend between boys and girls in secondary schools in Mandera County. It is at this level that gender disparity becomes deeply rooted and severe. The overall picture shows that out of 8,798 students enrolled in secondary, 6592 students constituting 74.9 percent are boys and 2,206 constituting 25.1 percent are girls. While the ratio at the county level portrays poor progress towards attainment of gender equity, the scenario becomes pathetic when the data is unpacked at sub- 
county level. The most shocking revelation is that in Lafey sub-county, while the general student enrollment of 140 students was very low, none was a female.

Table 3 : Enrollment in Secondary Schools in Mandera County

\begin{tabular}{|l|l|l|l|l|l|}
\hline Sub-County & Male & Percent & Female & Percent & Total \\
\hline Mandera East & 2544 & 67.4 & 1232 & 32.6 & 3776 \\
Lafey & 140 & 100.0 & 0 & 0.00 & 140 \\
Mandera West & 732 & 75.5 & 238 & 24.5 & 970 \\
Barissa & 350 & 86.2 & 56 & 13.8 & 406 \\
Mandera Central & 1194 & 77.5 & 346 & 22.5 & 1540 \\
Mandera North & 1655 & 83.2 & 334 & 16.8 & 1985 \\
Total & 6592 & 74.9 & 2206 & 25.1 & 8798 \\
\hline
\end{tabular}

Yet, in Table 2, we noted that there were 1105 girls in primary schools in the sub-county of Lafey. Does it mean there is a zero transition rate from primary to secondary schools for the girls? The situation is not any better in Barissa and Mandera North sub-counties. In Barissa sub-county, out of 406 students enrolled in secondary schools, 350 constituting 86.2 percent are boys while only 56 constituting 18.8 percent are girls. In Mandera North, out of 1985 students, 1655 students constituting 83.2 percent are boys while a paltry 344 constituting 16.8 percent are girls.

\subsection{Challenges Inhibiting the Attainment of EFA in Mandera County}

The final task of this paper was to find out the possible factors causing the attainment of EFA in Mandera County to be so elusive. The dismal rate of access to, and participation were caused by diverse challenges as portrayed in Figure 1.

Figure1: Challenges affecting Attainment of EFA in Mandera County, Kenya

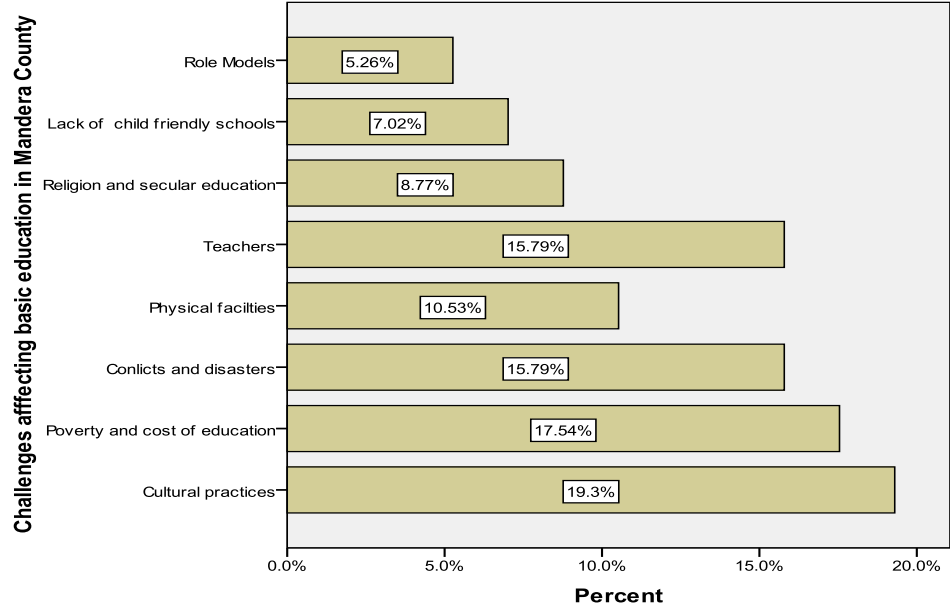

Figure 1 indicates that the most critical factors, in descending order of magnitude, according to the teachers who participated in the study, are: retrogressive and outdated cultural practices ; poverty at house-hold level and the high cost of education; Teacher related factors in terms of inadequacy, overload and use of ineffective teaching methods; Conflicts, disasters in schools and insecurity; Inadequate infrastructural and physical instructional resources; un-coordinated provision of religious ( Duksi and Madrasa) and secular educational modes of learning; Lack of child-friendly schools; and absence of role models for girls to emulate, amongst others.

These factors can conveniently be summarized under five categories: macro-level factors; school-based factors; home-based factors; policy and legal oriented interventions and individual level initiatives. The presentation and discussion of findings in this paper will, for sake of easier interpretation, follow the five categories.

\subsubsection{Macro-level factors}

\section{Poverty at household level and cost of education}

The main factors grouped in this category are: poverty as a result of pastoralist economy (17.54\%); conflicts, disasters and insecurity $15.79 \%$ ) constituting 33.33 percent of the total. The first critical macro-level factor cited by over a quarter of respondents $(17.54 \%)$ of is poverty at household level. This challenge of poverty and financing of education has been a long tradition of cost-sharing in education in Kenya, epitomized by the phenomenon of harambee (or self-help) schools. During the 1970s, the nominal commitment to 
providing free education sat uncomfortably with the practice of harambee collections, but in 1988 this contradiction was resolved when cost-sharing was formally made the basis of education financing. It is arguable that if education financing is conditional on the payment of fees of various kinds, it ceases to be a right, an entitlement of citizenship, but becomes instead a commodity that is available only to those with the money to buy it. In fact, even with the current FPE and FDSE in Kenya, the latent cost of education in terms of buying uniforms, building fund and transport becomes a real burden. And in a region as poor as Garissa County, a policy that makes parents responsible for maintaining the nations primary and secondary schools infrastructure as well as meeting the other hidden cost of education is bound to lead to falling enrollments and low quality of educational attainment as has been observed in the un-packed enrollment and participation rates within the subcounties of Mandera County. As a result, the PFE and FDSE do not seem to be meeting the intended goals due to the high latent cost of education.

The teachers interviewed, therefore described the latent cost of education, in all its manifestations, as the biggest single house-hold problem that limited children's access and participation in education. The teachers argued that the removal of all fees and all user-charges would be essential if participation were to be significantly increased in areas with noted poverty levels such as Mandera County.

As consequence of the high poverty level that has become grave given the devastating consequences of the drought that ravaged most parts of the NEP, child labour has manifested itself in high proportions. A big number of children are used as income earners to the household. They are engaged as domestic servants (maids, especially in urban and pre-urban areas), commercial activities especially across the border, while others especially those perceived to be more responsible are retained to herd livestock. Others, especially girls, are engaged in petty business in the market selling milk and foodstuff in market stalls. In most pastoralist communities, families do not view their livestock in monetary terms and are therefore reluctant to sell them for education purposes. Above all, large herds are viewed as a symbol of prestige that cannot be sold to purchase education (e.g. pay fees, and to cater for boarding expenses).

In Kenya, and especially in Mandera County, the incidence of poverty was highest for larger family sizes. The depth and severity of poverty is highest as household size increases. This aspect also explains the low educational level being pegged to poverty (Republic of Kenya, 2007:81). Larger households are associated with lower household per capita expenditure and unable to meet the latent school levies despite FPE and FDSE. This in effect reduces the school resources available to children in larger households. In such communities, when a boy or girl must benefit, the boy is given preference over the girl (but not the very bright ones who often assist their parents with livestock management). This is explained by the fact that larger households have to share the resources among more members; hence, decreasing resources are available to pay education inputs not provided by FPE and FDSE.

\section{Conflicts, disasters and lack of security}

The second challenge related to macro-level factors, cited by 17.8 percent of respondents is insecurity, lack of safety, and occasional conflict and lack of education in emergency initiatives to resettle those affected with frequent displacements in the study locale. Invariably, physical insecurity, income vulnerability and injustice provoke violence, and violence propels communities further into impoverishment (United Nations, 2013). Children are particularly more vulnerable in situations of conflict (World Development Report, 2011, WHO, 2012).Without peace; there can be no development (United Nations, 2013). Without development, there can be no enduring peace-yet peace and justice are perquisites for progress. We must acknowledge a principal lesson of the MDGs that peace and access to justice are not only fundamental human aspirations but cornerstones of sustainable development (United Nations, 2013). Without peace, children cannot go to school or access health clinics (United Nations, 2013).

The Government is cognizant of the safety of our school children, at all times, and everywhere cannot be over-emphasized. It is in this respect that the Government of Kenya developed a Safety Standards Manual which is both timely and invaluable. It underscores the Government's commitment to the safety and overall welfare of our learners and especially children. In fact, the safety of the learner is central to the provision of quality education in any country. While this is true for learners at all levels of education, it is particularly critical for learners at the basic education level in view of their relatively tender ages. Children of this early age are very vulnerable to threats such as bullying by their older colleagues, intimidation, verbal and physical abuse and all manner of harassments (Republic of Kenya, 2008; 2013).

The Ministry of education is currently advocating for more efforts to be directed towards education in emergencies, which is perceived to be the provision equality education opportunities that meet the physical protection, psychological development, and cognitive needs of people, which can be both life-sustaining and life-saving. In this, they perceive education as a fundamental right to all and in emergencies, children and other learners can be denied the right. Similarly, it is critical to provide a safe environment and provide life-saving and sustaining skills and support (Save the children, 2013; WHO, 2012). 
Apart from personal threats, insecurity for children can emanate from inappropriate school facilities and infrastructure. These may include poorly constructed classrooms and playing grounds, insufficient and brokendown toilet facilities, gender insensitive location of toilet and bathroom facilities, and inadequate and inappropriate desks and other furniture (Republic of Kenya, 2013). It was envisaged that, successful implementation of measures proposed in the manual would require partnerships with various stakeholders, among them learners, schools, parents, local communities, NGOs, religious organizations and other Community based organizations (CBOs). My sincere appeal to all stakeholders is that we should work together with focus and commitment to assure our schools, and particularly the children, adequate safety. It is apparent that the safety measures have not been implemented in primary and secondary schools in Garissa County.

\subsubsection{School-based factors}

The main school-based factors in this category are: Teacher related factors $(15.79 \%)$ and inadequate physical and instructional resources $(10.53 \%)$ constituting 26.32 percent of the total.

Majority of the indicated that the effect of FPE on teacher's teaching/learning methodology is profound due to increased pupil-teacher ratio in both primary and secondary schools due to over-enrolment and the resultant overcrowding in classes. This has in effect impacted negatively on teaching as teachers are unable to create effective teacher/student interaction. As a result, teachers are increasingly unable to give personal attention. The Government of Kenya acknowledges that although the pupil teacher ratio at the national level may show that the country has achieved the recommended ratio of 45:1, there are still regional disparities in the Coast and North Eastern provinces, where the pupil teacher ratio can be as high as 53:2 and 63:1 in 2007 respectively ( Republic of Kenya/UNESCO,2012). Despite the efforts of the government to recruit teachers, the teacher shortage still persists. The national teacher shortage stands at 61,235 for both primary and secondary schools. Of these, 32,235 are for primary schools (Griffin, 2010; Kiamba, 2011; Moula, 2010; Kinyanjui, 2011; Republic of Kenya, 2011).

The respondents indicated that it is now not uncommon for teachers to take advantage of the high enrolment as an excuse for not performing and engage in other income generating activities outside the school in order to compensate for their low pay. Teacher motivation and commitment to duty is believed to be at an alltime low by the respondents due to the current economic constraints. The added workload causes strain and stress among teachers, while lacks of incentives and poor remuneration have combined to affect the teachers' commitment to duty.

It was further stressed that inadequate physical and instructional resources, cited by 10.53 percent of the teachers, negatively affect effective implementation of basic education curriculum. They contended that the teaching and learning materials provided under FPE and FDSE are grossly inadequate. The delay in FPE and FDSE funds disbursement and the low level of the preparedness of school administrators to manage the funds are largely to blame for this. The facilities for school activities such as sanitary, classroom and sports facilities have been over-stretched in many schools and hardly reached some of the districts within Mandera County on a regular basis.

The Ministry of Educations position is that the textbook/pupil ratio for lower primary has improved from one textbook for more than 10 pupils before 2003 to 1:3 by 2007, reaching 1:2 in 2008 and 2009. For upper primary, TPR has improved from 1:2 in 2007 to almost 1:1 in 2008 and 2009 for the majority of schools. However, these have weakened sharply since 2009, and small schools do not benefit from economies of scale, and have ratios far higher than this (Value for Money Audit Report (2009). This confirms the teachers' position that instructional resources are grossly insufficient. The Ministry of Education admits that, in fact, the budgetary allocation by the Government of Kenya through the Ministry for the sector is insufficient and this does impact negatively on the provision of resources such as textbooks, PTRs and Retention Rates are also affected (Republic of Kenya, 2010c).

The low morale of students and teachers, cited by 11.22 percent of the teachers, is another crucial factors inhibiting effective implementation of basic education curriculum in primary and secondary schools in Kenya. This finding is of paramount importance because for the teachers to apply the skills that promote effective learning, they must be well motivated. Within the introduction of FPE and FDSE it has become increasingly difficult to motivate teachers who are confronted with an erratic and ever escalating number of learners due to the nomadic nature of learners in most areas in the study locale of Mandera County. The scenario has not been conducive to effective implementation of basic education curriculum in ways that encourage female learners to actively participate.

In addition, learners are exposed to unfriendly learning environment, especially in schools tha do not have adequate toilets for females, sanitary towels and provide midday meals that are appealing to female learners. The dilapidating buildings in some of the schools in Mandera County occasioned by erratic rainfalls and winds also scare the girls out of schools. 


\subsubsection{Home-based Factors \\ Retrogressive and outdated socio-cultural practices}

The main home-based factor cited by 19.3 percent of the respondents is the retrogressive and outdated socio-cultural practices. They reported that in Mandera County gender socialization is the overarching cause of the gender gap in primary and secondary schools. Girls are affected by sexual and gender-based violence, early marriages, and child and domestic labour at a disproportionately higher rate than boys, thereby falling further behind their peers and subjected to additional discriminatory practices within the classroom. Sexual and gender based violence continue to be a significant obstacle to girls education, particularly for mature girls attempting to pursue secondary education Parallel to the sexual harassment by male teachers and their male counterparts, it forces girls to withdraw or even avoid further educational opportunities. The practice of early marriage, too, precludes girls from pursuing further education.

In addition, Mandera County is largely composed of Somalis who are a patriarchal society. In such a societal setup, women and girls are accorded lower status. The community generally views girls as belonging to other people and not their families. For example, one teacher from Barissa Sub-County observed that educating a girl is viewed as watering somebody else's flower. The girls, therefore, are viewed as a form of investment to the family, hence to be married off before they are spoiled (read, educated). The girls are used to help fund education for their brothers. Girls who have acquired high levels of education are considered to be un-trusted (read alienated), and therefore not preferred for marriage. This mentality can be seen to be critical in explaining the current gender disparity in access to education at the disadvantage of females.

Furthermore, the Somali tradition dictates that a girl, from tender age, should be protected and trained to be a good wife and mother for the family. The immediate consequence of this, in Mandera County, is the high occurrence of early marriages, especially among the Somali communities. The young girl is, therefore, considered as useful source of work and income. It is clear that parents do not see much potential in their daughters. In fact, a common belief in many pastoralist communities is that the boy is the pillar of the family, and would take care of his parents and parent's livestock in their old age. Thus, when parents decide to invest their meager resources in education, the boy is given priority. Even then, the boy who actually goes to school is the one considered to be less intelligent and irresponsible. The bright boys are used to look after livestock because they can count them accurately and look after them keenly.

The other retrogressive cultural practice cited was early marriage and the accompanying bride-wealth is often justified under the umbrella of culture and maintaining family honour. A certain prospective restriction is accorded to the girls to the extent that they are barred from school under the pretext that schools cannot be trusted to protect the girls to remain virgins. As explained by the informant from Lafey sub-county of Mandera County:

Girls should not greet a man who is not a member of the close family due to natural body chemistry of the females. The implication is that culture is telling us that this girl cannot be with any other person except the father, the mother, the husband or the grave she goes into.... This girl cannot be trusted elsewhere because they believe that she might bring something bad like having a child out of wedlock.

The above cultural bondage on girls is extended to other retrogressive cultural practices especially female genital mutilation (FGM). The FGM targets girls from age 8 years onwards but before puberty. This process is perceived to curtail/inhibit the sexual urge of females hence restricts them to one husband. After the process, the girl views herself as mature and ready for marriage. This is an age where the girl is supposed to be in school, and therefore interferes with her academic progression, health notwithstanding.

Finally, child labour is arguably the most virulent force thwarting girls from pursuing education in Mandera County. While child-labour is outlawed in Kenya, it is still a significant obstacle to both boys and girls, although girls are affected at a much higher rates than boys particularly because much of what girls do may not be visible or statistically counted because it is performed domestically, outside the immediate purview of the labour market. In an older study in North Eastern Province in Kenya, Njeru and Orodho (2003) established that girls can start work at an earlier age than boys, work longer hours and oftentimes work as many hours as adults. Njeru and Orodho concluded in another study that a full time work schedule paired with formal primary education and the religious educational versions of Duksi and Madrasa in nomadic communities for a ten year old girl neither be sustainable, nor can it be adequate preparation for successful performance in Kenya Certificate of Primary Education (KCPE) examinations and eventual transition to secondary school. Thus, it is crystal clear that the brunt of labour placed on the shoulders of girls must be defrayed to enable girls not only enroll, be retained, and perform well unhindered in basic education in Kenya compared to their male counterparts not only in Mandera County, but in the entire Republic of Kenya. 


\subsubsection{Policy Intervention and Legal enforcement structures \\ Harmonization of religious education (Duksi and Madrasa) and formal education}

The main policy and legal oriented factors causing gender disparity in primary and secondary education in Mandera County are: coordination and harmonization of religious education provisions such as Duksi and Madrasa and the secular education curriculum $(8.77 \%)$ and intensification of child friendly schools $(7.02 \%)$ constituting 15.79 percent of the total. About 13.3 percent of the respondents indicated that there is the conflict between the religious and secular schools. The two compete for the same learners' time especially at ECD and lower primary. Since the community holds religious education much higher than secular education, the child is first given the religious education (Duksi School) before going for secular education at a later age (about 9 years). However, both religious and secular educations are necessary for holistic development of a child. There are cases where a child attends both, but this puts too much pressure on a child. Sometimes, the learner foregoes secular education completely in favour of Madrasa (Arabic system of education) studies.

\section{Child friendly schools}

The concept of child-friendly school has many interpretations. However, it is critical to note that one of the indicators of a child friendly school is one that provides adequate, separate sanitation facilities, such as separate toilets for boys and girls. In the absence of these facilities, female learners may feel unsafe and consequently, be forced not to stay long in school.

\subsubsection{Individual level Interventions}

\section{Increasing the number of Role models for the girl child}

The main individual level intervention is the need for role model for girls to emulate, cited by about 5.26 percent of the respondents. The absence of role model was seen to emanate from the fact that not only were few females in high ranking occupations in Mandera County such as Quality Assurance and Standards Officers and head-teachers particularly in secondary schools who were from the local community, they were also largely taught by male teachers in upper classes in primary and secondary schools. In Mandera County, it was established that female teachers are in majority in ECDE centers and lower primary classes. However, as the class levels advance to upper classes in primary schools and in secondary schools, the male dominance starts being felt, and this makes the few female learners in those classes uncomfortable. In addition, despite the fact that female are in the majority in some few upper primary schools, they hardly teach the traditionally feared subjects such as science and mathematics in schools in Mandera County. As a result, with female teachers only at the ECDE and lower primary levels, girls do not have strong women role models to whom they can reach out and receive moral and emotional support. This male dominated atmosphere is likely to breed instances of sexual harassment; male teachers and their male counterparts are ensured of impunity for their actions, and girls are afraid and unable to speak out about their experiences, especially in the power relationship of teacher-student.

With regard to role models, the female teachers in the sample argued that one solution to gender disparities constantly lauded for its influence on girls access and achievement is that of increasing the number of female teachers in the county, especially in upper primary and secondary school level. They argued that at lower primary school level, there is frequently a disproportionately higher rate of female teachers, but by the time the girl reaches secondary school level, this rate has been reversed. Female teacher provide crucial role models for girls, particularly when images of women in school curricular reinforce traditional gender roles. Girls look up to female teachers as figures of inspiration and emotional support, in addition to providing guidance for their education and future.

\section{Provision of sanitary materials and adequate nourishment}

It is evident that as girls progress through lower primary school to upper primary school, and if they are able to go on to secondary school, special provisions become increasingly scarce. Invariably, teenage girls need special provisions, such as sanitation facilities, provision of sanitary materials, and nourishment to offset their inability to invest time in domestic chores and other forms of child labour. If they do not have access to these individual facilities and resources, some unscrupulous individuals are likely to exploit the situation and make them drop out in order to provide for themselves and their families at an unreasonably tender age. Majority of girls in Mandera, especially in Lafey sub-County hardly benefit from the MoE/ UNIFEF initiative of assisting needy girls' access bursaries to enable them enroll in secondary schools. In fact, in the current financial year of 2013/2014 when this study was documented, there was no single girl in secondary schools in Lafey Sub-County of Mandera County.

\section{Conclusion and Recommendations}

Despite the spirited efforts through policies and other initiatives to attain the MDG and EFA goals, the majority of counties in Kenya, especially those located in North Eastern Province and specifically Mandera 
County, have fallen short of meeting the MDG and EFA goals and are not on track to meet them in full by the deadline of 2015. Nonetheless, this trajectory leaves room for improvement: the rhetoric promise to advance girls education in the study county of Mandera remains far from full implementation in policy and practice. Notwithstanding, however, recent successes in other counties outside nomadic pastoralist areas demonstrate the potential to reverse these policy lapses with promising examples of implementing child friendly schools, provision of sanitary towels, abolition of school fess through the FPE and FDSE, and the implementation of compulsory primary education. Organizations such as FAWE and UNICEF demonstrate how civil society and international NGOs, respectively, together with the Ministry of Education in Kenya, can provide scholarship assistance and other forms of subsidized financial assistance to offset the latent cost of girls education for families otherwise unable to afford the cost of education.

However, this is not the only panacea to the attainment of gender equity, especially in nomadic pastoralist counties such as Mandera County. The reality on the ground is that, although the Government of Kenya has recognized education as crucial precursor to development, and followed this with appropriate policies directly targeting gender disparities in primary and secondary education, the implementation and enforcement of these policies and interventions have not made any measurable progress in terms of enhancing girl-child education in basic education in Mandera County. It should be expected that with the current devolved government at county level and the well intentioned and focused policy frameworks in place that target girl's education, the county education office in collaboration with key stakeholders shall be required work harder in order to account for their interventions. In addition, rhetoric on girls' education has become extremely popular, but resources and logistical support have not been adequately distributed to support girls' education initiatives in the study locale. In fact, nearly every single policy document in education in Kenya mentions girls' education and the need for gender parity; it is almost as if it's merely the political correct language to use.

The reality on the ground is that the county governments, at least in Mandera County, seem not to have the capacity and commitment to really translate policies from rhetoric to practice .It is the contention of this paper that concerted efforts must be made both at national and county level of governance to ensure that girls education policy initiatives and interventions are allocated adequate funding and attention, to enable currently glaring gap between policy and practice, or rhetoric and reality, to be narrowed as a matter of urgency. Now that it is widely acknowledged in Kenya that girls' education is a precedent to development, and nobody should be left behind in development, the final panacea to dismantlement of differential gender disparity jinx in Mandera County is to use all means, legal and advocacy, to ensure that girls' education is made a reality in policy and practice, and not merely a rhetoric chimera.

\section{Acknowledgements}

The authors would like to thank the primary and secondary school teachers undertaking school-based undergraduate teacher education studies during the 2012/2013 academic year at Kenyatta University and Mount Kenya University, School of Education, for providing the data used in this study. The authors would also like to acknowledge the input of my three doctorate $(\mathrm{PhD})$ students from Kenyatta University and Mount Kenya University who assisted in the data analysis and report writing that resulted into this report. They are being mentored and are hence recognized as co-authors of this paper.

\section{References}

[1]. Brookings Institutions. (2013).Towards universal learning: What every child should learn. Brooks. Brunner, J.S.(1961).The Act of Discovery. Harvard Educational Review, Vol . No. 311961

[2]. Griffin (2010). Test model of the organizational antecedents of parental involvement and satisfaction with public education. Retrieved September 3, 2010 from http://Hum.sage pub.com.content/49/12/1549abstract.

[3]. Kinyanjui, K ,.( 2011). The Challenges of Youth Bulge in Africa: Marginalization, Conflict and Peace Building. Unpublished paper, Nairobi.

[4]. Muola, J. (2010). A Study of the Relationship Between Academic Motivation and Home Environment among Standard 8 pupils. Education Research and Review. Vol. 5 (5), 213 - 217.

[5]. Njeru H. N \& Orodho A.J (2003). Access and participation in secondary School Education in Kenya: Emerging Issues and Policy Implications, IPAR Discussion paper NO. 037/2003 ISBN 9966-948-27-9

[6]. Odhiambo.D. (2010). Task force on re-alignment of education to the Constitution 2010 and Vision 2030 and beyond. The Government of Kenya.

[7]. Republic of Kenya. (2005a).) Sessional Paper No. 1 on Policy Reforms for Education, Training and Research: Meeting the Challenges of Education Training and Research in the $21^{\text {st }}$ Century. Ministry of Education, Science and Technology (MOEST Nairobi: MOEST.

[8]. - -------(2005b). Kenya Education Sector Support Programme 2005 - 2010: Delivering Quality Education and Training to All Kenyans. Nairobi: MOEST.

[9]. (2001): Children's Act, Government Printer, Nairobi

[10]. - ------- (2005a) Economic Survey. Government Printers Nairobi

[11]. --------- (2005b) Kenya Education Sector Support Programme (KESSP). Government. Printers 
[12]. --------(2007a). Gender and Education Policy in Kenya. Government Printer. Nairobi.

[13]. --------(2007b).Harmonization of the Legal framework on Education Training and Research: A Report of the task force on review and harmonization of the legal framework on education, training and research.

[14]. ----(2008).Draft report of the Adult and Continuing Education. Government Printers. Nairobi.

[15]. ------(2009a). Policy for Alternative Provision of Basic Education and Training. Ministry of Education Science and Technology. Nairobi.

[16]. ----(2009b).Policy Framework on Nomadic Education in Kenya. Ministry of Education and UNICEF. Nairobi.

[17]. ----.(2010a). The Constitution of Kenya 2010. The Attorney General. Nairobi.

[18]. ------(2010b).Child friendly Schools Manual. Ministry of Education. Nairobi.

[19]. -----(2010c). Economic Stimulus. Office of the Prime Minister. Nairobi.

[20]. ------(2010d).Kenya Demographic Health Survey. Bureau of Standards. Nairobi.

[21]. ------(2012a).Sessional Paper No.14 of 2012 on realigning education and training to the Constitution of Kenya 2010 and Vision 2030 and beyond. Ministry of Education Science and Technology. Nairobi. Kenya.

[22]. -----(2012b).A Policy Framework for re-aligning education to the Constitution 2010 and Vision 2030 and beyond.

[23]. ----(2013). The Basic Education Act 2013 No.14 Of 2013. Nairobi

[24]. Republic of Kenya/UNICEF( 2012).Education for All (EFA) End of Decade Assessment (2001-2010). Ministry Of Education and INICEF. Nairobi.

[25]. UNESCO (2004a).Monitoring Report 2005 through the UNESCO International Bureau of Education, Geneva. Andersen, L. W. (2004). Increasing Teacher Effectiveness. 2nd ed. Paris, UNESCO International Institute for Educational Planning.

[26]. ---------(2004b): Challenges of Implementing Free Primary Education in Kenya: Assessment Report

[27]. ------ (2005a): EFA Global Monitoring Report 2005: Education for All, The Quality Imperative, UNESCO, Paris

[28]. UNESCO. (2005b). Education For All (EFA) Global Monitoring Report. UNESCO, Paris. United Nations (UN). (2004). Millennium development goals: Progress report 2004. Available at www.un.org/millenniumgoals/mdg2004chart.pdf. Retrieved January $25^{\text {th }} 2010$.

[29]. --------(2010). Education for All Global Monitoring Report: Reaching the Marginalized. Paris.

[30]. ------(2011).Conceptual evaluation and policy development in lifelong learning. Hamburg .UNESCO. Institute of Lifelong Learning.

[31]. --------(2012). Systematic monitoring of education for All. Paris: United Nations Educational, Scientific and Cultural Organization,( UNESCO).

[32]. United Nations. (2005a): MDG Status Report for Kenya for 2005, UN

[33]. -------- (2005b): UN Millennium Project, Task Force on Education and Gender Equality

2005 .

[34]. -------(2011). The Hidden Crisis : Armed conflict and education. Education for All Global Monitoring Report . http://www.unesco.org. Geneva.

[35]. -----(2012). Youth and Skills: Putting Education to work. EFA Monitoring Report .

[36]. -------(2013). A New Global Partnership: Eradicating Poverty and Transform Economy through Sustainable Development. The Report of the High-Level Panel of Eminent Persons on the Post- 2015 Development Agenda. The United Nations.

[37]. World Education Forum (2000). Dakar Framework for Action.

[38]. World Bank. (2008). National Assessment of Education Achievement Vol.1 : Assessing indicators of achievement. Washington D.C.

[39]. --------(2010).World Development Indicators. Retrieved Nov.2010 from http://www.publications.worldbank.org.

[40]. --------(2012).Gender Equity and Development. World Development Reports. Washington D,C. Wright, S. P., Horn, S. P., Sanders, W. L. (1997). Teacher and Classroom Context. Personnel Evaluation in Education, Vol. 11: 57-7. 